\title{
Sediment Trapping by Emerged Channel Bars in the Lowermost Mississippi River during a Major Flood
}

\author{
Bo Wang and Y. Jun Xu *
}

School of Renewable Natural Resources, Louisiana State University Agricultural Center, 227 Highland Road, Baton Rouge, LA 70803, USA; E-Mail: bwang13@1su.edu

* Author to whom correspondence should be addressed; E-Mail: yjxu@1su.edu; Tel.: +1-225-578-4168; Fax: +1-225-578-4227.

Academic Editor: Miklas Scholz

Received: 18 September 2015 / Accepted: 30 October 2015 / Published: 4 November 2015

\begin{abstract}
The formation of channel bars has been recognized as the most significant sediment response to the highly trained Mississippi River (MR). However, no quantitative study exists on the dynamics of emerged channel bars and associated sediment accumulation in the last 500-kilometer reach of the MR from the Gulf of Mexico outlet, also known as the lowermost Mississippi River. Such knowledge is especially critical for riverine sediment management to impede coastal land loss in the Mississippi River Delta. In this study, we utilized a series of satellite images taken from August 2010 to January 2012 to assess the changes in surface area and volume of three large emerged channel bars in the lowermost MR following an unprecedented spring flood in 2011. River stage data were collected to develop a rating curve of surface areas detected by satellite images with flow conditions for each of the three bars. A uniform geometry associated with the areal change was assumed to estimate the bar volume changes. Our study reveals that the 2011 spring flood increased the surface area of the bars by $3.5 \%$ to $11.1 \%$, resulting in a total surface increase of $7.3 \%$, or $424,000 \mathrm{~m}^{2}$. Based on the surface area change, we estimated a total bar volume increase of $4.4 \%$, or $1,219,900 \mathrm{~m}^{3}$. This volume increase would be equivalent to a sediment trapping of approximately 1.0 million metric tons, assuming a sediment bulk density of 1.2 metric tons per cubic meter. This large quantity of sediment is likely an underestimation because of the neglect of subaqueous bar area change and the assumption of a uniform geometry in volume estimation. Nonetheless, the results imply that channel bars in the lowermost MR are capable of capturing a substantial amount of sediment during floods, and that a thorough assessment of their long-term change can
\end{abstract}


provide important insights into sediment trapping in the lowermost MR as well as the feasibility of proposed river sediment diversions.

Keywords: channel bars; fluvial geomorphology; channel dynamics; sediment transport; lowermost Mississippi River

\section{Introduction}

The Mississippi River Delta (MRD), a 25,000 $\mathrm{km}^{2}$ dynamic region on the southeastern coast of Louisiana in the USA, has been experiencing rapid land loss since the early 20th century [1-4]. The loss rate varied from $17 \mathrm{~km}^{2} /$ year in 1913 to $102 \mathrm{~km}^{2} /$ year in 1980 and averaged about $43 \mathrm{~km}^{2} /$ year during 1985-2010 [5,6]. In the past 80 years, a total of $4877 \mathrm{~km}^{2}$ coastal land have lost [6]. A number of factors have been attributed to the rapid land loss, including riverine sediment reduction due to upstream dam construction and river engineering, subsidence, and sea level rise [7]. It has been projected that, if no actions were taken, at least another $2118 \mathrm{~km}^{2}$ land of Louisiana's coast would be lost over the next 50 years [8,9]. This possesses a serious threat to the energy industry, river transportation, and commercial fisheries in this region, all of which have the level of national importance.

Sediment from the Mississippi River (MR) is a precious resource for sinking costal Louisiana. Currently, diversions of the lowermost MR are being proposed for introducing the riverine sediment to various wetland habitats on the sinking coast of the Mississippi River Delta [10]. Success of these projects will rely not only on the selection of river diversion locations but also on the actual sediment availability along the lowermost MR. The need for such information is especially critical at the planning stage, because it is essential that river engineering helps in maximally capturing the sediment resource while ensuring navigation safety and flood protection.

A number of studies have been conducted on sediment availability assessment for the Mississippi-Atchafalaya River System (MARS). For the Mississippi River main channel at Tarbert Landing, Meade and Moody [11] reported an average annual suspended sediment load (SSL) of 145 million metric tons (MT) over the period 1987-2006. For the same location, a report by the U.S. Army Corps of Engineers (USACE) [12] gave an average annual SSL of 134 MT for the decade 1989-1998 and a nearly 10\% reduced load (123 MT) for the following decade. In a recent study, however, Rosen and $\mathrm{Xu}$ [13] reported an average annual suspended sediment load of $126 \mathrm{MT}$ for the three decades of 1980-2010, with an insignificant but slightly increasing trend from 1990 to 2010. For the Mississippi River's largest distributary, the Atchafalaya River at Simmesport, Xu [14] reported an average annual suspended sediment load of 64 MT over the period 1975-2004, while the USACE report [12] gave an annual SSL of 48 MT for 1999-2008 and 75 MT for 1989-1998. In spite of the discrepancy among the reports, these estimates provide insights into magnitude and timing of riverine sediment in MARS. However, the locations for which sediment loads were made are far from the river mouths: Tarbert Landing is located nearly $500 \mathrm{~km}$ upstream from the outlet of the MR main channel to the Gulf of Mexico, while Simmesport is approximately $220 \mathrm{~km}$ from the mouth of the Atchafalaya River main channel to the Gulf of Mexico. Therefore, it is not clear how much of the sediment loads estimated for the two far-upstream locations can actually reach the coast. 
In recent years, research on sediment availability of the MARS has focused on assessing sediment loss downstream Tarbert Landing and Simmesport. In their sediment budget study for the upper 182-km reach of the Atchafalaya River Basin, Rosen and Xu [15] found an annual sediment trapping of $\sim 10 \%$ from 1980 to 2010 , spatially occurred mainly in the lower basin areas with larger swamp and open water areas. In a shorter-term sediment budgeting for the flood years 2008-2010, Allison et al. [16] reported that nearly half of the total annual suspended sediment on the MR and Red River were trapped between the Old River Control Structures and the Mississippi-Atchafalaya exits to the Gulf of Mexico. For the MR main channel, they found an annual sediment loss of about 67 MT total suspended sediment within the 74-km river reach between Tarbert Landing and St. Francisville, part of the east side of the MR is not leveed. Therefore, Allison et al. attributed the loss to a possible overbank sedimentation and river channel bed accumulation. In a follow-up study Smith and Bentley [17] could, however, only find a marginal sedimentation (2 MT/year) from the three flood years on the unleeved flood plain, the previously assumed large overbank storage area. This quantity of sediment makes only $3 \%$ of the estimate by Allison et al., leaving 97\% of the estimated sediment loss uncounted for.

The MR has been extensively modified for flood control and navigation since the 1920s [18]. The modifications included the construction of levees, bank revetments, artificial cutoffs, training dikes and reservoirs on the major tributaries [19]. As a result, the river channel was constrained to laterally accrete and shift to form natural cutoffs of meanders, instead, the vertical accretion on bars occurred as a morphological response of the alluvial river [19,20]. Despite the general observations existed, quantitative studies of channel bars in the MR are scarce and they are limited to headwater areas and gravel bed channels [21-23]. After a thorough literature review, we could not find any studies on lower MR channel bar dynamics and believe our study to be the first.

From May to June in 2011, an unprecedented flood of the Mississippi River occurred because of the combination of snowmelt and heavy rain. The river crested $19.32 \mathrm{~m}$ at TBL on the 18th of May 2011, which was nearly $75 \mathrm{~cm}$ higher than the crest stage of the $1927 \mathrm{MR}$ flood $(18.57 \mathrm{~m})$. A field river sampling in the lowermost Mississippi River during 12-14 May 2011 [24] found a sharp rise of sediment concentrations. This large river flood provides a unique opportunity for assessing changes in large emerged channel bars in the lowermost MR. We hypothesized that during this extreme flood event, a substantial quantity of riverine sediments, especially sands, would be trapped by channel bars. In this study, we utilized satellite images taken before and after the 2011 spring flood to first quantify the change in surface area of the channel bars and then to estimate the associated change in volume of these channel bars. The primary goal of the study was to assess flood effects on channel bar dynamics and sediment accumulation in the lowermost Mississippi River. Estimation of possible sediment accumulation on these bars is important for understanding sediment sources and availability for developing river diversion plans and strategies in the lowermost Mississippi River.

\section{Study Area}

The channel bars investigated in this study are located shortly downstream the river diversion control structure of the lowermost Mississippi River, the Old River Control Structures (ORCS) $\left(31^{\circ} 04^{\prime} 36^{\prime \prime} \mathrm{N}, 91^{\circ} 35^{\prime} 52^{\prime \prime} \mathrm{W}\right)$. ORCS diverts the MR into two channels (Figure 1): the Mississippi River main channel and the Atchafalaya River. Under normal flow conditions, about $25 \%$ of the MR's 
water is diverted into the Atchafalaya River that also carries the entire flow of the Red River. The control structure is designed to prevent the MR from changing its course to the Atchafalaya River, which was the river's old channel several thousand years ago $[25,26]$, by seeking a shorter course to the Gulf of Mexico [27]. During high flows, larger volume of the MR's water is allowed to the Atchafalaya River, in order to reduce flood risk downstream to the cities of Baton Rouge and New Orleans.

According to the common classifications of position and shape [28], the study area includes two mid-channel bars - Shreves Bar and Miles Bar - and one point bar-Angola Landing, and they are located approximately 18, 24, and 26 kilometers downstream of the ORCS (Figure 1), respectively. All the three bars are located within a meander with the elongated Shreves Bar on the top and the Miles Bar at the end of the meander.
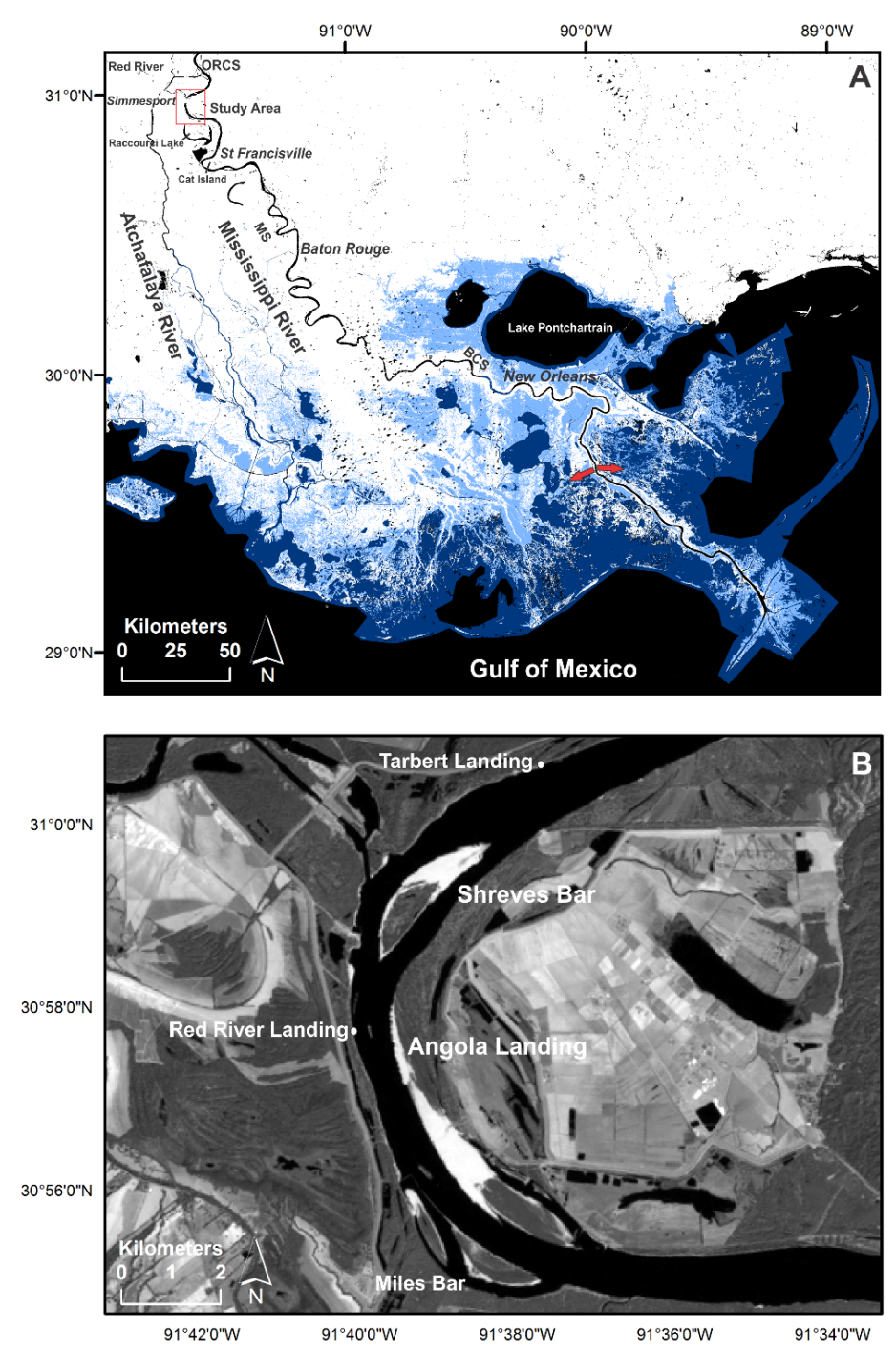

Figure1. (A) Map of southeastern Louisiana, with the locations of Old River Control Structure (ORCS), Morganza Spillway (MS), Bonnet Carré Spillway (BCS), cities, and proposed sediment diversions (red arrows). Blue area is the potential sinking area for the period up to 2050 based upon the elevation and sea level trend data from the U.S. Geological Survey and National Oceanic and Atmospheric Administration [29]; (B) The locations of Shreves Bar, Angola Landing and Miles Bar, Tarbert Landing (TBL) and Red River Landing (RRL). 
In this study, we obtained daily river stage data from the Red River Landing (RRL) gauge station $\left(30^{\circ} 57^{\prime} 39^{\prime \prime} \mathrm{N}, 91^{\circ} 39^{\prime} 52^{\prime \prime} \mathrm{W}\right.$; river kilometer 487, or river mile 302.4; USACE Gauge ID: 01120), which is the closest gauge station to the studied channel bars. The U.S. National Oceanic and Atmospheric Administration (NOAA) uses the station's stage for lowermost Mississippi River flood prediction. We also collected river discharge and sediment records from the Tarbert Landing (TBL) gauge station $\left(31^{\circ} 00^{\prime} 30^{\prime \prime} \mathrm{N}, 91^{\circ} 37^{\prime} 25^{\prime \prime} \mathrm{W}\right)$, which is located at river kilometer 493 (river mile 306.3), about 16 kilometers downstream the ORCS. The station provides the longest discharge and sediment records for the lowermost Mississippi River where both the U.S. Geological Survey (USGS) and the U.S. Army Corps of Engineers (USACE) have a monitoring station (USGS Station ID: 07295100 and USACE Gauge ID: 01100). It is to note that the sediment records at Tarbert Landing are currently under review by the USGS and USACE due to possible errors.

\section{Long-term Hydrologic Conditions and the 2011 Spring Flood}

Long-term (1973-2013) average discharge of the Mississippi River at TBL is 15,027 cubic meter per second (cms), varying from $3143 \mathrm{cms}$ in 1988 to $45,844 \mathrm{cms}$ in 2011 . Seasonally, discharge of the lowermost Mississippi River is high during the winter and spring and low during the summer and early fall. For its flood warning prediction for the lowermost MR, NOAA defines five flow stages at RRL: (1) Low Flow Stage (river stage: $<9.8 \mathrm{~m}$ ); (2) Action Flow Stage (river stage: 9.8-12.1 m); (3) Intermediate Flow Stage (river stage: 12.1 to $14.6 \mathrm{~m}$ ); (4) High Flow Stage (river stage: 14.6 to $16.8 \mathrm{~m}$ ), and (5) Peak Flow Stage (river stage: $>16.8 \mathrm{~m}$ ). Using a stage-discharge analysis, Rosen and Xu [13] separated the corresponding flow regimes $<13,000 \mathrm{cms}$ for Low Flow Stage, 13,000-18,000 cms for Action Flow Stage, 18,000-25,000 cms for Intermediate Flow Stage, 25,000-32,000 cms for High Flow stage, and $>32,000 \mathrm{cms}$ for Peak Flow Stage.

During the spring of 2011, extreme flooding conditions prevailed along the MR due to a combination of snow melt and heavy rain. The river stage at RRL reached High Flow Stage (i.e., $14.6 \mathrm{~m}$ ) in early May and remained above the stage in June. The river crested $19.32 \mathrm{~m}$ on 18 May 2011. The average stage at RRL was $18.21 \mathrm{~m}$ in May and $16.86 \mathrm{~m}$ in June.

\section{Estimation of Bar Area and Volume Changes}

\subsection{Collection of Satellite Imagery and River Stage Data}

A total of 22 cloud-free Landsat Surface Reflectance Climate Data Record (CDR) images (Path 23 Row 39) taken in 2010, 2011, and 2012 were collected from USGS (Table 1). Level-1 Landsat 4-5 Thematic Mapper (TM) and Landsat 7 Enhanced Thematic Mapper Plus (ETM+) data were processed using the Landsat Ecosystem Disturbance Adaptive Processing System (LEDAPS) [30]. LEDAPS considers water vapor, ozone, geopotential height, aerosol optical thickness, and digital elevation when it deals with atmospheric correction [31,32]. The CDR products include Top of Atmosphere (TOA) Reflectance, Surface Reflectance, Brightness Temperature, and masks for clouds, cloud shadows, adjacent clouds, land, and water [33]. In our study, the product of surface reflectance was utilized to acquire surface area of the bars because it is easier to detect area change over time without the 
atmospheric effect. In addition, the mask product of water and land was used to aid to delineate the outlines of the bars.

Table 1. Dates and product numbers of Landsat CDR images used in this study and the corresponding daily river stages at Tarbert Landing of the Mississippi River.

\begin{tabular}{cccccc}
\hline Date & River Stage $(\mathbf{m})$ & Landsat CDR products No. & Date & River Stage (m) Landsat CDR products No. \\
\hline & Before the Flood & & During and after the Flood \\
\hline 3 August 2010 & 12.05 & LE70230392010215EDC01 & 26 May 2011 & 18.93 & LT50230392011146CHM01 \\
27 August 2010 & 9.97 & LT50230392010239EDC00 & 3 June 2011 & 18.50 & LE70230392011154EDC00 \\
9 December 2010 & 8.71 & LE70230392010343EDC00 & 11 June 2011 & 17.45 & LT50230392011162EDC00 \\
2 January11 & 7.18 & LT50230392011002CHM01 & 13 July 2011 & 13.76 & LT50230392011194EDC00 \\
26 January 2011 & 6.84 & LE70230392011026EDC00 & 22 August 2011 & 9.35 & LE70230392011234EDC00 \\
11 February 2011 & 7.55 & LE70230392011042EDC00 & 30 August 2011 & 8.66 & LT50230392011242EDC00 \\
19 February 2011 & 7.85 & LT50230392011050EDC00 & 7 September 2011 & 8.63 & LE70230392011250EDC00 \\
15 March 2011 & 14.12 & LE70230392011074EDC00 & 01 October 2011 & 7.17 & LT50230392011274EDC00 \\
16April 2011 & 13.86 & LE70230392011106EDC00 & 17 October 2011 & 6.42 & LT50230392011290EDC00 \\
& & & 25 October 2011 & 5.80 & LE70230392011298EDC00 \\
& & & 2 November 2011 & 6.65 & LT50230392011306EDC00 \\
& & & 10 November 2011 & 6.79 & LE70230392011314EDC00 \\
& & & & 11.77 & LE70230392012029EDC00 \\
\hline
\end{tabular}

To identify river flow conditions in connection with the satellite images, river stage records at RRL were collected from USACE for August 2010-January 2012. The data were also used to develop numeric relations between surface area of the channel bars and the river stages (see more in Sections 4.2 and 4.3).

\subsection{Estimation of Bar Surface Area Changes}

For estimating area change of the bars, satellite images were chosen following two rules: (1) images must be taken within several months before and after the flood because this could maximally reflect the change of surface area was caused by the flood; and (2) images taken dates must have similar river stages which is necessary for comparing area change. Based on these rules, the images taken on 2 January 2011 and 1 October 2011 were chosen, when the river stage was at $7.18 \mathrm{~m}$ and $7.17 \mathrm{~m}$, respectively.

It is important to choose one suitable band in the image to digitize the boundary of the channel bars. In general, near-infrared band-band $4(0.76-0.90 \mu \mathrm{m})$ and shortwave band-band $5(1.55-1.75 \mu \mathrm{m})$ are good at differentiating land and water because water has almost no reflection and shows near black color in these bands. However, in the band 4 image, bare soil on the channel bars displays a similar character with vegetated soil on the riverbank. This makes it difficult to distinguish the bar from bank soil. Therefore, band 5 was used to digitize the bar. The digitization process was performed in ArcGIS 10.3 (ESRI, Redlands, CA, USA). For reducing feature identification error, all images were digitized at the same scale and followed the same rules made by the operator.

ERDAS IMAGINE 2013 (Leica Geosystems Geospatial Imaging, LCC, GA, USA) was used to assess the distribution of the area change. Through subtracting the band 5 values of the post-flood image by the band 5 values of the pre-flood image, we obtained the threshold values that were used to 
locate the change of surface feature. Because the display values in the surface reflectance image is multiplied by 10,000 , the value of water body is usually lower than 100 , whereas bare soil in the bars is over 3000. As a result, after the subtraction, larger positive values $(+3000)$ indicated water changed to land and the smaller negative values $(-3000)$ indicated land changed to water.

\subsection{Estimation of Bar Volume Changes}

Previous research has proved multi-temporal multi-beam echosoundings, mobile and terrestrial laser scanning, and Acoustic Doppler Current Profiler are able to effectively estimate the dynamics of channel bars by measuring the elevation change of the bars [23,34-36]. However, these studies usually focus on the mechanisms of the morphological change, especially, in a relatively small study sites (a few hundred meters). Our study aims to quantify the sediment trapped by large bars caused by an unprecedented flood. The tools mentioned above, however, are not useful for achieving this study objective because no measurements were taken within a short period of time before the 2011 Mississippi River large flood. In investigation of large flood effects on channel bars, pre-flood data are often missing [37]. Therefore, we developed a surface area-river stage rating curve for each of the three bars based upon available satellite images taken before and after the flood.

Firstly, the areas of the three bars were calculated in each image followed the method described in Section 4.2. However, with the increase of the stage, some area was submerged and it was difficult to tell the outlines of the bars. For solving this problem, the bar outlines on the day that had the lowest stage were used as baselines to make sure the bar outlines on other days within these baselines. The image used here was taken on 25 October 2011. The river stage on that day was $5.80 \mathrm{~m}$, which was very close to the lowest stage $(5.65 \mathrm{~m})$ in 2011 . Another problem was that with the increase of the river stage, especially when it was over the flood stage $(14.63 \mathrm{~m})$, bars that were partly covered by the water turn dark in the band 5 image, which could cause an underestimation of the surface area. By comparison, band 4 was used as substitute to estimate the bar surface area when the river stage was over $14.63 \mathrm{~m}$. Secondly, according to the surface areas at different stages, the rating curve was assumed to be a polynomial curve because the area usually becomes smaller with the increase of the river stage as displayed in Figure 2.

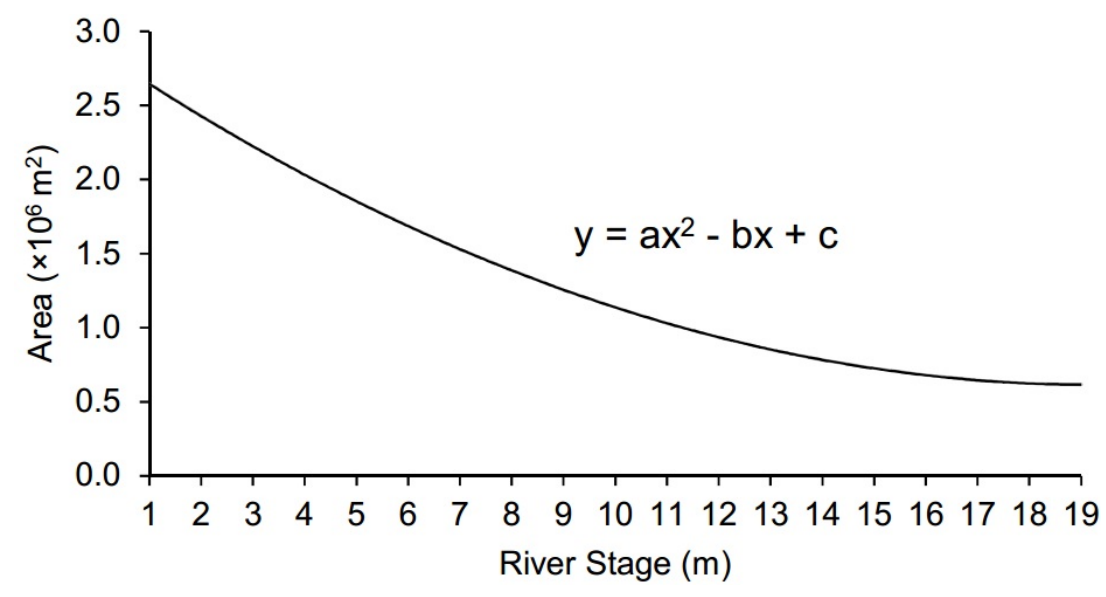

Figure 2. A hypothetical relationship between channel bar surface area and river stage at Tarbert Landing of the lowermost Mississippi River. 
The following equation was used to compute standard error for the estimate from a surface area-river stage rating curve:

$$
\mathrm{SE}=\sqrt{\frac{\sum(\hat{y}-y)^{2}}{N-P}}
$$

where SE is the standard error of the estimate, $N$ is the sample size, $P$ is the number of the parameters in the model, $\hat{y}$ is the predicted value and $\mathrm{y}$ is the actual value.

The channel bar volumes $\left(V_{S}\right)$ pre and post the 2011 spring flood were calculated for each bar based on the integral:

$$
\begin{aligned}
V_{s}=\int_{D_{l}}^{D_{h}}\left(a x^{2}-b x+c\right) d x & =\left.\left(\frac{a x^{3}}{3}-\frac{b x^{2}}{2}+c x\right)\right|_{D_{l}} ^{D_{h}}=\left(\frac{a D_{h}{ }^{3}}{3}-\frac{b D_{h}{ }^{2}}{2}+c D_{h}\right)- \\
& \left(\frac{a D_{l}^{3}}{3}-\frac{b D_{l}^{2}}{2}+c D_{l}\right)
\end{aligned}
$$

where $V_{s}$ is the channel bar volume, $D_{h}$ is the highest river stage, $D_{l}$ is the lowest stage, and $a, b$ and $c$ are constants.

\section{Results}

\subsection{Surface Area Change of Shreves, Angola Landing and Miles bars}

The false color images (band 432) show the bars before, during and after the 2011 spring flood (Figure 3). White color indicates bare soil areas and red color indicates vegetated areas. Before the flood, when the river stage was at $7.18 \mathrm{~m}$, bare soil and vegetated area were clearly visible in the satellite image. With the increase of the stage to $18.93 \mathrm{~m}$ on 26 May 2011, all bare soils and part of the vegetated areas on the bars were inundated (Figure 3B). After the flood when the river stage dropped to $7.17 \mathrm{~m}$, which was nearly the same river stage like that before the flood, sediment accumulation could be seen along the bars. Miles Bar used to be a single bar (image not shown) and became braided in the recent decade. All the heads of these channel bars appeared to mainly sand accumulation and their tails were covered by vegetation.

There were both gain and loss of the surface area in the three studied bars after the flood (Figure 4). Area loss occurred mainly in the northern part of the Shreves Bar while area gain occurred in the western and eastern sides. A minor area loss was found at Angola Landing and the main gain occurred along the western side. For Miles Bar, land gain occurred on the west side of the braided bars.

As a whole, all three bars showed a net gain from 2 January 2011 to 1 October 2011 (Table 2). The surface area of Shreves Bar increased from 1,743,800 $\mathrm{m}^{2}$ to $1,804,500 \mathrm{~m}^{2}$ (or a $3.5 \%$ increase). Angola Landing showed a $224,700 \mathrm{~m}^{2}$ increase (or an $8.1 \%$ increase) of its surface area from 2,784,300 $\mathrm{m}^{2}$ before the flood to $3,008,900 \mathrm{~m}^{2}$ after the flood. The braided Miles Bar increased from 1,259,200 $\mathrm{m}^{2}$ to $1,397,900 \mathrm{~m}^{2}$ (or an $11.0 \%$ increase). The total surface area increase of the three bars following the 2011 spring flood amounted to $424,000 \mathrm{~m}^{2}$ (or a $7.3 \%$ increase). 

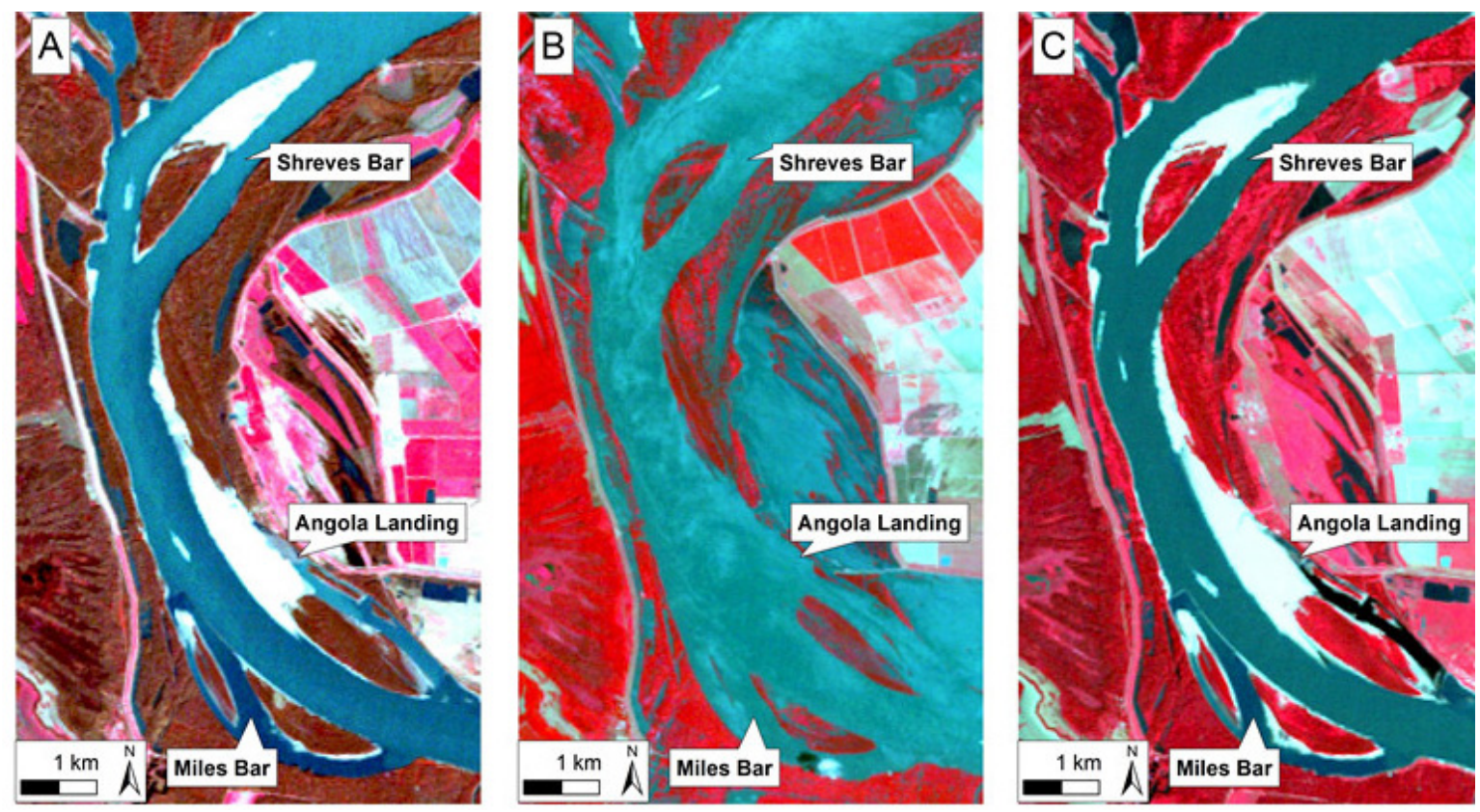

Figure 3. False color images (band 432) showing bare soil (white) and vegetated areas (red) of three large channel bars near Tarbert Landing of the Mississippi River on 2 January 2011 (A); 26 May 2011 (B); and 1 October 2011 (C).

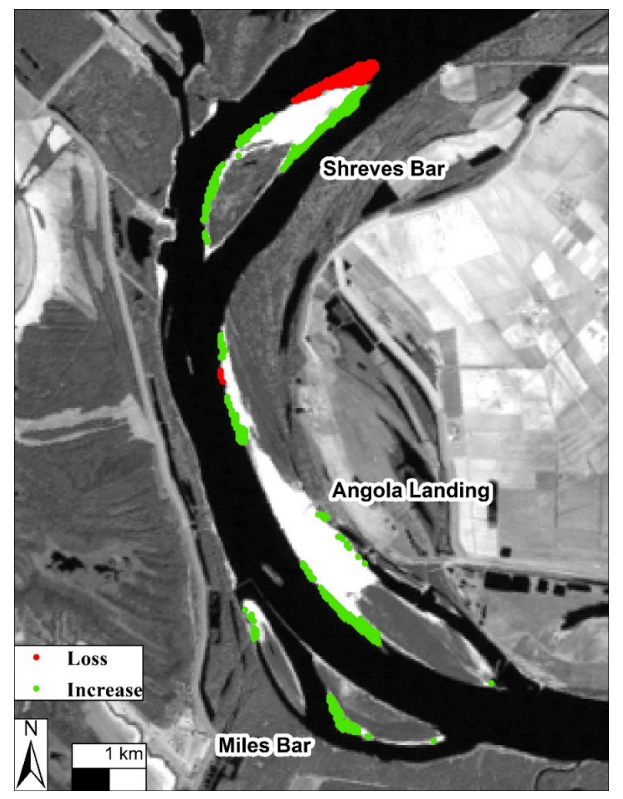

Figure 4. Changes in surface area of three large mid-channel bars near Tarbert Landing of the Mississippi River after the 2011 spring flood.

Table 2. Changes $(\Delta)$ in surface area of three large channel bars near Tarbert Landing of the Mississippi River before and after the 2011 Spring Flood.

\begin{tabular}{|c|c|c|c|c|c|}
\hline Date & River Stage (m) & Shreves Bar & Angola Landing $\left(\mathbf{m}^{2}\right)$ & Miles Bar & Total \\
\hline 2 January 2011 & 7.18 & $1,743,800$ & $2,784,300$ & $1,259,200$ & $5,787,300$ \\
\hline 1 October 2011 & 7.17 & $1,804,500$ & $3,008,900$ & $1,397,900$ & $6,211,300$ \\
\hline \multicolumn{2}{|c|}{$\Delta$} & $+60,600$ & $+224,700$ & $+138,700$ & $+424,000$ \\
\hline \multicolumn{2}{|c|}{$\Delta(\%)$} & $+3.5 \%$ & $+8.1 \%$ & $+11.0 \%$ & $+7.3 \%$ \\
\hline
\end{tabular}




\subsection{River Stage-Surface Area Rating Curves for Shreves, Angola Landing and Miles bars}

The pre- and post-flood surface areas estimated with 22 satellite images for the three bars were given in Table 3. The relationships between the surface areas and the river stages taken on the dates were found best represented by a second order polynomial equation, where the increase of area associated with a decrease of river stage (Figure 5). The correlation coefficients $\left(\mathrm{R}^{2}\right)$ of the rating curves were all high, i.e., above 0.98 . The surface area-river stage curves based on the equations show that the three post-flood curves are all above the pre-flood curves. Interesting is that the post-flood area of Miles Bar was clearly higher than its pre-flood area in the lower river stage, but became unchanged in the higher river stage, indicating the bar's greater horizontal expansion. On the other side, Shreves Bar and Angola Landing both showed comparably smaller area change in the lower river stage, but an increasing change in the higher river stage, suggesting a greater vertical expansion.

Table 3. Estimated surface areas of three large channel bars in the lowermost Mississippi River and the river stages of the dates when the satellite images were taken.

\begin{tabular}{cccccc}
\hline Flood & Date & River Stage $(\mathbf{m})$ & Shreves Bar & Angola Landing $\left.\mathbf{( m}^{\mathbf{2}}\right)$ & Miles Bar \\
\hline & 3 August 2010 & 12.05 & 930,500 & 937,600 & 845,500 \\
& 27 August 2010 & 9.97 & $1,194,900$ & $1,894,700$ & 956,400 \\
& 9 December 2010 & 8.71 & $1,408,400$ & $2,327,600$ & $1,071,500$ \\
Before & 2 January 2011 & 7.18 & $1,743,800$ & $2,784,300$ & $1,259,200$ \\
the flood & 26 January 2011 & 6.84 & $1,807,000$ & $2,924,500$ & $1,312,800$ \\
& 11 February 2011 & 7.55 & $1,681,500$ & $2,726,700$ & $1,250,200$ \\
& 19 February 2011 & 7.85 & $1,554,000$ & $2,498,800$ & $1,108,700$ \\
& 15 March 2011 & 14.12 & 612,800 & 727,000 & 734,900 \\
& 16 April 2011 & 13.86 & 747,700 & 721,300 & 692,500 \\
\hline \multirow{5}{*}{ 26 May 2011 } & 18.93 & 717,100 & 694,600 & 572,300 \\
& 3 June 2011 & 18.50 & 731,700 & 700,200 & 620,700 \\
& 11 June 2011 & 17.45 & 763,100 & 747,600 & 661,700 \\
& 13 July 2011 & 13.76 & 837,300 & 846,400 & 758,700 \\
During & 22 August 2011 & 9.35 & $1,334,000$ & $2,159,000$ & $1,107,200$ \\
the flood after & 30 August 2011 & 8.66 & $1,439,200$ & $2,412,400$ & $1,124,700$ \\
& 7 September 2011 & 8.63 & $1,402,500$ & $2,369,600$ & $1,205,600$ \\
& 1 October 2011 & 7.17 & $1,804,500$ & $3,008,900$ & $1,397,900$ \\
& 17 October 2011 & 6.42 & $1,909,900$ & $3,259,400$ & $1,394,800$ \\
& 25 October 2011 & 5.80 & $2,178,900$ & $3,699,600$ & $1,638,600$ \\
& 2 November 2011 & 6.65 & $1,884,000$ & $3,245,600$ & $1,432,600$ \\
& 10 November 2011 & 6.79 & $1,819,200$ & $3,098,300$ & $1,387,300$ \\
& 29 January 2012 & 11.77 & 937,100 & $1,061,300$ & 851,600 \\
\hline
\end{tabular}




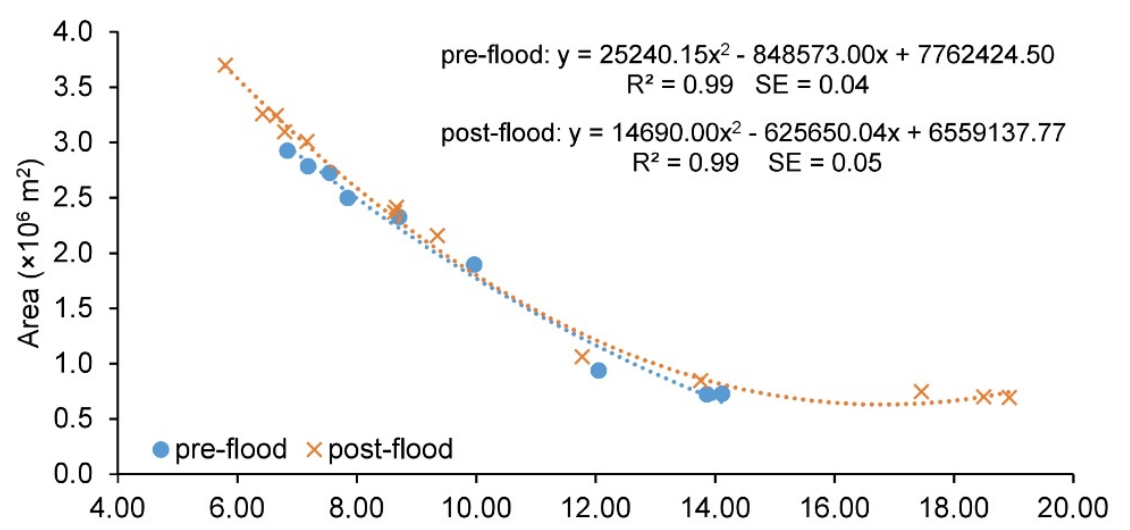

(A)

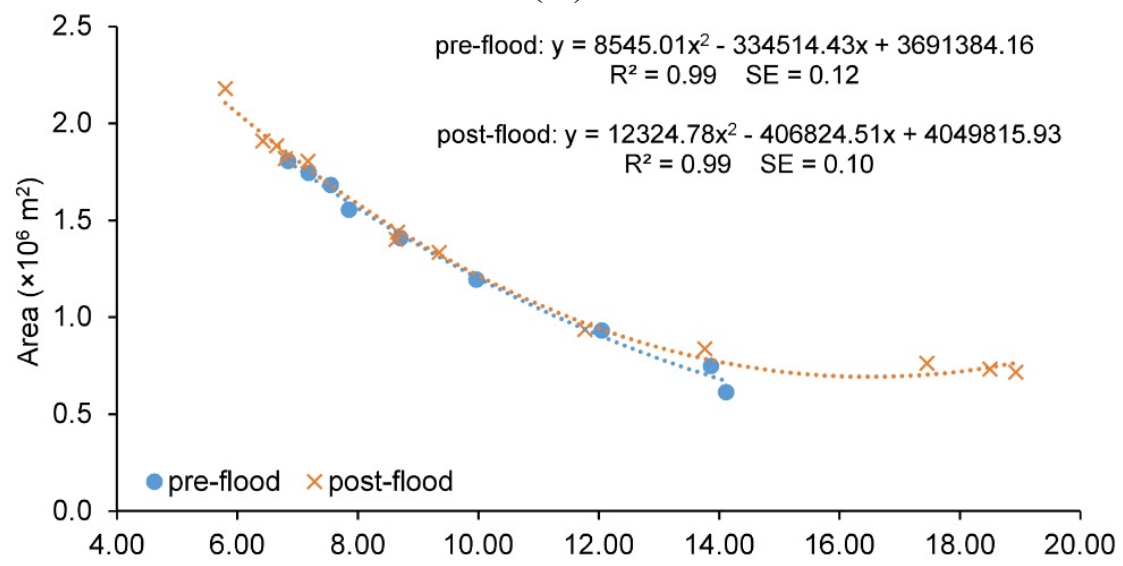

(B)

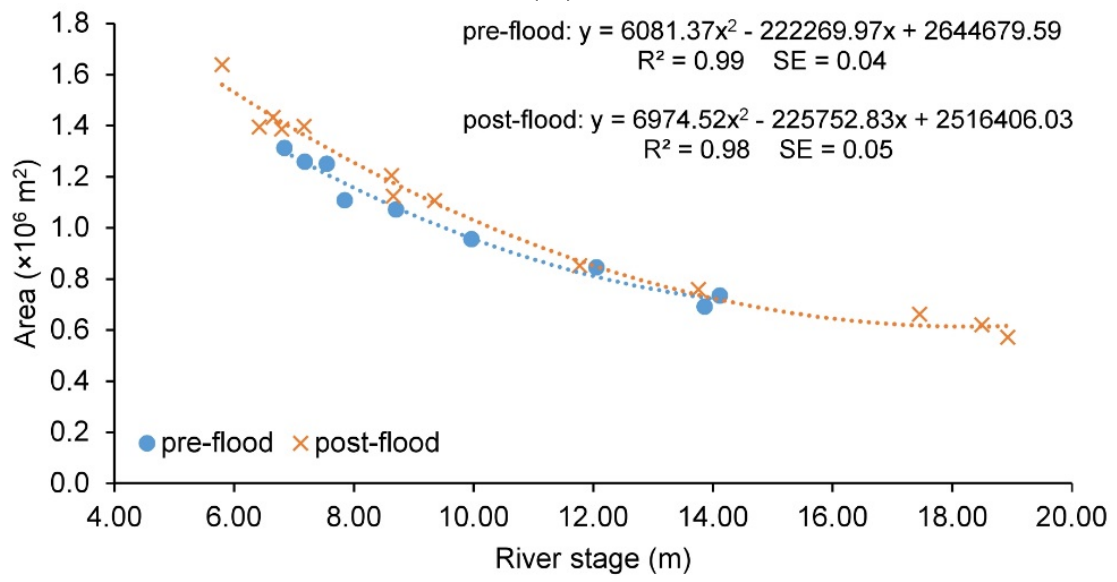

(C)

Figure 5. Rating curves of surface area-river stage for Shreves Bar (A); Angola Landing (B); and Miles Bar $(\mathbf{C})$ near Tarbert Landing in the lowermost Mississippi River. SE $\left(\times 10^{6} \mathrm{~m}^{2}\right)$ is the standard error of the estimate.

\subsection{Volume Change of Shreves, Angola Landing and Miles bars}

For comparison of the bar volume changes, a same range of river stages was used for the three studied bars. The stage range was $6.84 \mathrm{~m}-14.12 \mathrm{~m}$, based upon which the bar volumes were calculated for the pre- and post-flood periods (see Equation (1)). The estimated volume of the three channel bars all increased after the 2011 spring flood (Table 4). The volume gain for Shreves Bar, Angola Landing and Miles Bar was 236,300 $\mathrm{m}^{3}, 526,900 \mathrm{~m}^{3}$ and $456,700 \mathrm{~m}^{3}$, respectively, or in a percentage rate of 
$2.8 \%, 4.3 \%$ and $6.6 \%$. The total volume gain of the three channel bars above the river stage of $6.84 \mathrm{~m}$ was $1,219,900 \mathrm{~m}^{3}$ or a $4.4 \%$ increase.

Table 4. Changes $(\Delta)$ in volume of three large channel bars near Tarbert Landing in the lowermost Mississippi River before and after the 2011 spring flood.

\begin{tabular}{ccccc}
\hline Period & Shreves Bar & Angola Landing $\left.\mathbf{( m}^{\mathbf{3}}\right)$ & Miles Bar & Total \\
\hline Pre-flood & $8,458,700$ & $12,234,900$ & $6,896,600$ & $27,590,200$ \\
Post-flood & $8,695,000$ & $12,761,800$ & $7,353,300$ & $28,810,100$ \\
\hline$\Delta$ & 236,300 & 526,900 & 456,700 & $1,219,900$ \\
$\Delta(\%)$ & $+2.8 \%$ & $+4.3 \%$ & $+6.6 \%$ & $+4.4 \%$ \\
\hline
\end{tabular}

\section{Discussion}

Kesel [38] analyzed the historic channel bar size and volume from 1880 to 1963 in the Mississippi River. It was concluded that there were few bars in the Lower Mississippi River and there was relatively little change in their bar size and volume. However, our findings indicate that one single river flood can have effects on the surface area and volume of the channel bars in the river reach. The increase of surface area is 60,600, 224,700 and 138,700 $\mathrm{m}^{2}$ for Shreves Bar, Angola Landing and Miles Bar, respectively. These numbers are all greater than the standard error of the estimates for their respective rating curves, which means the area change estimated by the digitation is statistically significant. Located in the middle of the river channel, Shreves Bar showed the large gain and loss in its surface area after the 2011 flood (Figure 4). In general, for channel bars, heavier materials such as gravels and coarse sands on bar heads are resistant to flow [22] and erosion occurs on bar margins [39,40]. The 2011 extreme flood, however, caused a strong erosion of the bar head of Shreves Bar with sediment deposition on its margins. The erosion was caused by high stream power during the flood, which removed the sediments on bar head. For the deposition on bar margins, it may be caused by lateral accretion at the low flow after the flood. Ashworth, et al. [41] studied the evolution of a mid-channel bar in a large sand-bed braided rivers and they found the high flow during the flood produced high sediment transport rates and caused bar-top vertical aggradation while the falling and low-stages caused lateral accretion. They reported the possible reason for lateral accretion was flow divergence at the bar head. Based on their theory, the deposition occurred on the eastern side of Shreves Bar was caused by the lateral accretion. The slower flow inside of the bend of Shreves Bar caused deposition on the bar's west side. Due to the erosion, $0.06 \mathrm{~km}^{2}$ net increase of surface area of Shreves Bar was the lowest increase among the three bars. The deposition for Angola Landing and Miles Bar were both inside bends depositions. Angola Landing had more deposition suggests that the larger the sandbar, the more capacity it has to capture the sediment during the flood.

In this study, we estimated a total volume increase of 1.2 million $\mathrm{m}^{3}$ for the three studied bars during the 2011 spring flood. It is important to note that (1) the estimation is made for the bar area above the river stage of $6.84 \mathrm{~m}$ at RRL; and (2) the estimation is based on the assumption that the bars have a uniform geometry. Although we are not certain how the volume below the $6.84 \mathrm{~m}$ river stage has changed, the estimation is likely a gross underestimation of actual changes in the subaqueous area of the three studied channel bars. At the stage of $14.12 \mathrm{~m}$, the submerged area included all bar heads and part of bar tails of Shreves Bar and Angola Landing, and nearly half of Miles Bar. Because sediment 
size on the bar surface becomes finer along the bar [17], it suggests there would be muddy sediment deposited on tails of the bars during the flood. At the range of stage below $6.84 \mathrm{~m}$, it is no doubt that there were a large amount of sediment trapped there during the flood. In addition; the surface area-river stage rating curve was utilized to estimate the volume change covering the post-flood period (July 2011 to January 2012), which was a flood recession period. Studies have reported that part of the newly deposited sediment could be eroded during the falling limb of floods [23,42]. It suggests that the calculated volume after the flood was possible less than the actual captured volume during the flood. Therefore, it is reasonable to believe that the 1.2 million $\mathrm{m}^{3}$ volume gain is a conservative estimate of the trapped sediments by the three bars during the 2011 flood.

The sediments trapped by the three channel bars during the 2011 spring flood can contain all grain sizes of sediment. Based on a recent field trip and observation four years after the 2011 spring flood, sediments trapped on the bars should primarily be sands. Assuming a bulk density of 1.2 metric tons per cubic meter (i.e., a typical bulk density for silt—pure soil), the total volume of trapped sediment during the 2011 flood would be about 1.0 million metric tons. Joshi and $\mathrm{Xu}$ [43] analyzed the long-term relationship between discharge and sand load for Tarbert Landing and developed a daily discharge $(q)$ and daily sand load $(S)$ rating curve as below:

$$
\ln (\mathrm{S})=-0.6382 \ln (\mathrm{q})^{2}+14.3 \ln (\mathrm{q})-67.139\left(R^{2}=0.87, \mathrm{SE}=0.496\right)
$$

Daily total sand load from 1 March 2011 to 31 August 312011 was calculated according to this rating curve (Figure 6). During this flood period, daily sand load fluctuated between 28,642 and 371,010 tonnes/day, and a total sand load was about 34.0 MT. If our 1.5 MT estimate of trapped sediment were pure sand, that would be only about $4.4 \%$ of the total sand load passing the three bars.

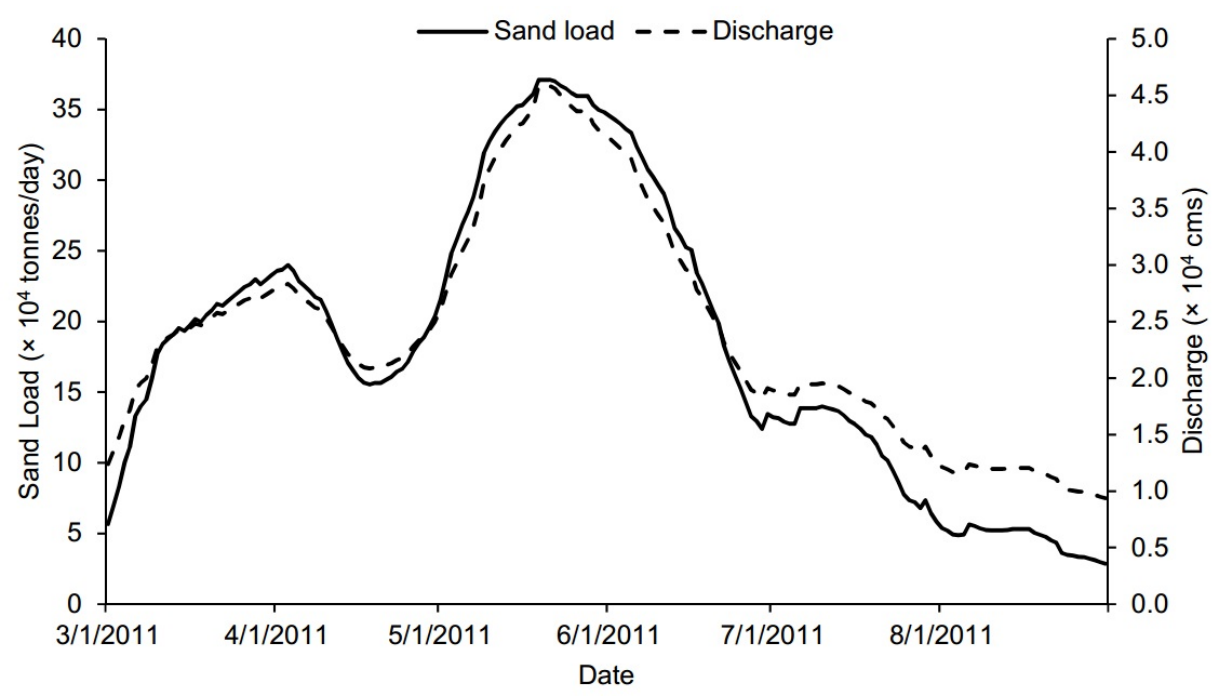

Figure 6. River discharge (cms) and estimated daily sand load (tonnes/day) at Tarbert Landing pre and post the 2011 Mississippi River spring flood.

From their study on a three-year sediment budget (2008-2010), Allison et al. [16] reported an average loss of $67 \mathrm{MT} /$ year total suspended sediment in the river reach from TBL to St. Francisville at river kilometer 419 , and $80 \%$ of the sediment loss was sand, i.e., about $54 \mathrm{MT} /$ year sand. They attributed the large loss to a deposition in the channel bed and overbank storage. In a follow-up study by Smith 
and Bentley [17], however, only about 2 MT/year muddy sediment deposited by overbank storage was found in the unleeved Cat Island and Raccourci Lake area. Considering our 1.0 MT sediment trapping in the three bars, a large quantity of the sediment loss is still uncounted for. There are other large channel bars in the river reach between the Tarbert Landing and St. Francisville. These bars could also have trapped substantial sediment during the flood. Further study is needed to elucidate the role of these bars in sediment accumulation in the lowermost MR.

A large amount of sediment may have been also transported to downstream of the study site during the flood. Kroes, et al. [44] reported that 1.03 MT of sediment was deposited in the Atchafalaya River Basin through the Morganza Spillway, located right below our study site, in a 54-day release period during the 2011 flood. The Bonnet Carré Spillway (BCS), a 2300-m-width flood control construction located in about $51 \mathrm{~km}$ upstream of downtown New Orleans that allows floodwater from the Mississippi River to flow into the Lake Pontchartrain. It diverted 4.9 million $\mathrm{m}^{3}$ sand during the 42 days operation from 9 May to 20 June in 2011 [45]. Through the comparison we found the increased volume in the three bars was about $25 \%$ of the total diverted sand by BCS. Although the BCS was not designed for maximizing sediment capture, there is little doubt that a large amount of sand was transported downstream.

For the suggested sediment diversions by the Louisiana Coastal Protection and Restoration Authority [10] which may be only operated in the certain time periods, such as during Intermediate Flow Stage and High Flow Stage or the rising limb of flood pulses $[28,46]$. Our findings presented here indicate that if the sediment diversions open during these periods, the channel bars in the lowermost Mississippi River can trap a considerable amount of sediment, which may impair the capacity of diverting sediment to the river surrounding wetland. Many studies have reported substantial reduction of sediment loads in the Lower Mississippi River during the past century [5,7,47]. Increasing evidence suggests that significant amount of sediment is being trapped in the lower MR [19,27]. However, the MR delta ecosystem would be better served if the sediment could be delivered to the coastal areas of the delta that are currently eroding and subsiding (Figure 1), though engineering solutions for providing such delivery are in need of development. Nonetheless, the large quantity of sediment trapped in the Lower MR, which may well exceed one billion tons, is a critical resource for restoration of the Mississippi River Delta, and it needs to be carefully managed. There are about a dozen large mid-channel and point bars in the river reach below the studied sites. It is not clear how much sediment these bars could trap under normal and during high flow conditions. Future studies are required to answer the question.

\section{Conclusions}

This study is the first quantitative assessment of a major flood on morphological changes and the associated sediment accumulation of emerged channel bars in the lowermost Mississippi River. The findings show that channel bars in this highly trained river are capable of trapping a substantial quantity of sediment during a flood. Long-term change of the channel bars may have profound effects on downstream river channel morphology and sedimentation, and the accumulated sediment could be used as a critical source for restoring the sinking Mississippi River Delta. There is a need to further investigate other large channel bars in the lowermost Mississippi River in order to quantify the 
sediment accumulation rate over the past several decades. Furthermore, the study demonstrates that the surface area-river stage rating curve is a useful approach in assessing areal and volumetric changes of channel bars.

\section{Acknowledgments}

Bo Wang is a recipient of the Coastal Science Assistantship Program (CSAP) from the Louisiana Coastal Protection and Restoration Authority (CPRA). This research is also benefited from a U.S. National Science Foundation project (award number: 1212112) and a U.S. Department of Agriculture Hatch Fund project (project number: LAB94230). The statements, findings, and conclusions are those of the authors and do not necessarily reflect the views of the funding agencies. The authors are also thankful for the U.S. Geological Survey and the U.S. Army Corps of Engineers for making the satellite images and river discharge, stage, and sediment data available for this research.

\section{Author Contributions}

Bo Wang carried out image and numeric analyses, and wrote the first manuscript draft. Yi Jun Xu developed the study concept, provided oversight throughout the study, and revised the manuscript. All authors read and approved the final manuscript.

\section{Conflicts of Interest}

The authors declare no conflict of interest.

\section{References}

1. Britsch, L.D.; Dunbar, J.B. Land loss rates: Louisiana coastal plain. J. Coast. Res. 1993, 9, 324-338.

2. Craig, N.J.; Turner, R.E.; Day, J.W. Land loss in coastal Louisiana (USA). Environ. Manag. 1979, 3, 133-144.

3. Gagliano, S.M.; Meyer-Arendt, K.J.; Wicker, K.M. Land loss in the Mississippi River deltaic plain. Trans. Gulf Coast Assoc. Geol. Soc. 1981, 31, 295-300.

4. Scaife, W.; Turner, R.; Costanza, R. Coastal Louisiana recent land loss and canal impacts. Environ. Manag. 1983, 7, 433-442.

5. Kesel, R.H. The decline in the suspended load of the Lower Mississippi River and its influence on adjacent wetlands. Environ. Geol. Water Sci. 1988, 11, 271-281.

6. Couvillion, B.R.; Barras, J.A.; Steyer, G.D.; Sleavin, W.; Fischer, M.; Beck, H.; Trahan, N.; Griffin, B.; Heckman, D. Land Area Change in Coastal Louisiana from 1932 to 2010; U.S. Geological Survey Scientific Investigations Map 3164; U.S. Department of the Interior: Washington, DC, USA; U.S. Geological Survey: Reston, VA, USA, 2011; p. 12.

7. Boesch, D.F.; Josselyn, M.N.; Mehta, A.J.; Morris, J.T.; Nuttle, W.K.; Simenstad, C.A.; Swift, D.J.P. Scientific Assessment of Coastal Wetland Loss, Restoration and Management in Louisiana; Coastal Education and Research Foundation (CERF): Fort Lauderdale, FL, USA, 1994. 
8. Couvillion, B.R.; Steyer, G.D.; Hongqing, W.; Beck, H.J.; Rybczyk, J.M. Forecasting the effects of coastal protection and restoration projects on wetland morphology in coastal Louisiana under multiple environmental uncertainty scenarios. J. Coast. Res. 2013, 67, 29-50.

9. Day, J.W.; Boesch, D.F.; Clairain, E.J.; Kemp, G.P.; Laska, S.B.; Mitsch, W.J.; Orth, K.; Mashriqui, H.; Reed, D.J.; Shabman, L.; et al. Restoration of the Mississippi Delta: Lessons from hurricanes Katrina and Rita. Science 2007, 315, 1679-1684.

10. Coastal Protection and Restoration Authority (CPRA). Louisiana's Comprehensive Master Plan for a Sustainable Coast; CPRA: Baton Rouge, LA, USA, 2012; p. 188.

11. Meade, R.H.; Moody, J.A. Causes for the decline of suspended-sediment discharge in the Mississippi River system, 1940-2007. Hydrol. Process. 2010, 24, 35-49.

12. Filippo, S. Mississippi River Sediment Availability Study: Summary of Available Data; ERDC/CHL CHETN-IX-22; US Army Corps of Engineers:Vicksburg, MS, USA, 2010.

13. Rosen, T.; Xu, Y.J. A hydrograph-based sediment availability assessment: Implications for Mississippi River sediment diversion. Water 2014, 6, 564-583.

14. $\mathrm{Xu}, \mathrm{Y} . J$. Long-term sediment transport and delivery of the largest distributary of the Mississippi River, the Atchafalaya, USA. In Sediment Dynamics for a Changing Future; Banasik, K., Horowitz, A., Owens, P.N., Stone, M., Walling, D.E., Eds.; IAHS Press: Wallingford, UK, 2010; pp. 282-290.

15. Rosen, T.; Xu, Y.J. Estimation of sedimentation rates in the distributary basin of the Mississippi River, the Atchafalaya River Basin, USA. Hydrol. Res. 2015, 46, 244-257.

16. Allison, M.A.; Demas, C.R.; Ebersole, B.A.; Kleiss, B.A.; Little, C.D.; Meselhe, E.A.; Powell, N.J.; Pratt, T.C.; Vosburg, B.M. A water and sediment budget for the lower Mississippi-Atchafalaya River in flood years 2008-2010: Implications for sediment discharge to the oceans and coastal restoration in louisiana. J. Hydrol. 2012, 432, 84-97.

17. Smith, M.; Bentley, S.J., Sr. Sediment capture in flood plains of the Mississippi River: A case study in cat island national wildlife refuge, Louisiana. IAHS Publ. 2014, 367, 442-446.

18. Harmar, O.P.; Clifford, N.J.; Thorne, C.R.; Biedenharn, D.S. Morphological changes of the lower Mississippi River: Geomorphological response to engineering intervention. River Res. Appl. 2005, 21, 1107-1131.

19. Smith, L.M.; Winkley, B.R. The response of the lower Mississippi River to river engineering. Eng. Geol. 1996, 45, 433-455.

20. Biedenharn, D.S.; Thorne, C.R. Magnitude-frequency analysis of sediment transport in the lower Mississippi River. Regul. Rivers Res. Manag. 1994, 9, 237-251.

21. Hooke, J.M. The significance of mid-channel bars in an active meandering river. Sedimentology 1986, 33, 839-850.

22. Li, Z.; Wang, Z.; Pan, B.; Zhu, H.; Li, W. The development mechanism of gravel bars in rivers. Quat. Int. 2014, 336, 73-79.

23. Wintenberger, C.L.; Rodrigues, S.; Claude, N.; Jugé, P.; Bréhéret, J.-G.; Villar, M. Dynamics of nonmigrating mid-channel bar and superimposed dunes in a sandy-gravelly river (Loire River, France). Geomorphology 2015, 248, 185-204. 
24. Ramirez, M.T.; Allison, M.A. Suspension of bed material over sand bars in the lower Mississippi River and its implications for Mississippi Delta environmental restoration. J. Geophys. Res. Earth Surf. 2013, 118, 1085-1104.

25. Fisk, H.N. Geological Investigation of the Alluvial Valley of the Lower Mississippi River; U.S. Department of the Army, Mississippi River Commission: Vicksburg, MS, USA, 1944; p. 78.

26. Fisk, H.N. Geological Investigation of the Atchafalaya Basin and the Problem of Mississippi River Diversion; Wterways Experiment Station: Vicksburg, MS, USA, 1952; p. 145.

27. Mossa, J. Historical changes of a major juncture: Lower old river, Louisiana. Phys. Geogr. 2013, 34, 315-334.

28. Hooke, J.M. Processes of channel planform change on meandering channels in the UK. John Wiley \& Sons: Chichester, UK, 1995; pp. 87-115.

29. National Oceanic and Atmospheric Administration (NOAA). Sea Level Trends (Center for Operational Oceanographic Products). Available online: http://tidesandcurrents.noaa.gov/sltrends/ sltrends.html (accessed on 28 October 2015).

30. Wolfe, R.; Masek, J.; Saleous, N.; Hall, F. Ledaps: Mapping North American disturbance from the landsat record. In Proceedings of the IEEE International Geoscience and Remote Sensing Symposium, Anchorage, AK, USA, 20-24 September 2004; pp. 1-4.

31. Kotchenova, S.Y.; Vermote, E.F. Validation of a vector version of the 6 s radiative transfer code for atmospheric correction of satellite data. Part II. Homogeneous lambertian and anisotropic surfaces. Appl. Opt. 2007, 46, 4455-4464.

32. Vermote, E.F.; Tanre, D.; Deuze, J.L.; Herman, M.; Morcette, J.J. Second simulation of the satellite signal in the solar spectrum, 6s: An overview. IEEE Trans. Geosci. Remote Sens. 1997, 35, 675-686.

33. Masek, J.G.; Vermote, E.F.; Saleous, N.E.; Wolfe, R.; Hall, F.G.; Huemmrich, K.F.; Feng, G.; Kutler, J.; Teng-Kui, L. A landsat surface reflectance dataset for North America, 1990-2000. IEEE Trans. Geosci. Remote Sens. Lett. 2006, 3, 68-72.

34. Lotsari, E.; Vaaja, M.; Flener, C.; Kaartinen, H.; Kukko, A.; Kasvi, E.; Hyyppä, H.; Hyyppä, J.; Alho, P. Annual bank and point bar morphodynamics of a meandering river determined by high-accuracy multitemporal laser scanning and flow data. Water Resour. Res. 2014, 50, 5532-5559.

35. Williams, R.D.; Rennie, C.D.; Brasington, J.; Hicks, D.M.; Vericat, D. Linking the spatial distribution of bed load transport to morphological change during high-flow events in a shallow braided river. J. Geophys. Res. Earth Surf. 2015, 120, 604-622.

36. Kasvi, E.; Vaaja, M.; Alho, P.; Hyyppa, H.; Hyyppa, J.; Kaartinen, H.; Kukko, A. Morphological changes on meander point bars associated with flow structure at different discharges. Earth Surf. Process. Landf. 2013, 38, 577-590.

37. Eaton, B.C.; Lapointe, M.F. Effects of large floods on sediment transport and reach morphology in the cobble-bed sainte Marguerite River. Geomorphology 2001, 40, 291-309.

38. Kesel, R.H. Human modifications to the sediment regime of the lower Mississippi River flood plain. Geomorphology 2003, 56, 325-334.

39. Tsujimoto, T. Development of Sand Island with Vegetation in Fluvial Fan River under Degradation; American Society of Civil Engineers: Reston, VA, USA, 1998; pp. 574-579.

40. Wu, W. Computational River Dynamics; CRC Press: Boca Raton, FL, USA, 2008. 
41. Ashworth, P.J.; Best, J.L.; Roden, J.E.; Bristow, C.S.; Klaassen, G.J. Morphological evolution and dynamics of a large, sand braid-bar, Jamuna River, Bangladesh. Sedimentology 2000, 47, 533-555.

42. Mueller, E.R.; Grams, P.E.; Schmidt, J.C.; Hazel, J.E., Jr.; Alexander, J.S.; Kaplinski, M. The influence of controlled floods on fine sediment storage in debris fan-affected canyons of the Colorado River Basin. Geomorphology 2014, 226, 65-75.

43. Joshi, S.; Xu, Y.J. Sand availability assessment under different flow conditions of the Lower Mississippi River at tarbert landing during 1973-2013. Water 2015, submitted for publication.

44. Kroes, D.E.; Schenk, E.R.; Noe, G.B.; Benthem, A.J. Sediment and nutrient trapping as a result of a temporary Mississippi River floodplain restoration: The Morganza Spillway during the 2011 Mississippi River flood. Ecol. Eng. 2015, 82, 91-102.

45. Nittrouer, J.A. Backwater hydrodynamics and sediment transport in the lowermost Mississippi River Delta: Implications for the development of fluvial-deltaic landforms in a large lowland river. IAHS-AISH Publ. 2013, 358, 48-61.

46. Mossa, J. Sediment dynamics in the lowermost Mississippi River. Eng. Geol. 1996, 45, 457-479.

47. Kesel, R.H. The role of the Mississippi River in wetland loss in Southeastern Louisiana, USA. Environ. Geol. Water Sci. 1989, 13, 183-193.

(C) 2015 by the authors; licensee MDPI, Basel, Switzerland. This article is an open access article distributed under the terms and conditions of the Creative Commons Attribution license (http://creativecommons.org/licenses/by/4.0/). 